\title{
Traditional Rulers and the Operation of Local Administration in the Republic of Benin
}

\author{
By S. Bamidele Ayo
}

\begin{abstract}
"In spite of the eagerness and grim determination to make the old order change and yield to the new, there is a particular institution which has stood its ground and which, rather than yield place to new modernizing influences, has continued to dig its roots deeper into the life of the people. This is the Chieftaincy institution. In the history of Nigeria, particularly in the Northern and in the Western parts the chieftaincy institution is as old as the history of the people themselves. It is established by tradition and hallowed by custom ".'
\end{abstract}

\section{Introduction}

The above quotation, though on Nigeria, graphically depicts the situation of the chieftaincy institution and traditional rulers in the present-day Republic of Benin, and in many other independent African states.

The purpose of this paper is to examine the role of traditional ruling elites in the administration of the Republic of Benin. Attention is focused upon administration at the local level. The analysis is done against the background of the dominating role of traditional aristocracy in pre-colonial times, of their use as an intermediary structure of authority by the French colonial masters.

It is argued in this paper that the pre-colonial era represented the 'golden age for the traditional aristocracy. They lost their power and sovereignty as a result of colonization. However, the French colonial masters made use of them. Though the new rulers of the post-colonial state no longer recognize the traditional rulers as part of the structures of authority, these modern political elites realise that the traditional rulers cannot be ignored.

The paper is divided into three sections. The first section takes a look at traditional aristocracy in the pre-colonial era. The second section centres on the integration of the traditional rulers into colonial administration which made them a part of colonial outfit. The third section examines, globally, the attitudes of the leaders of the post-colonial state to traditional authorities.

1 Brigadier (now retired Major-General), David Jemibewon: $A$ Combatant in Government, Heinemann Educational Books, Nigeria Ltd., Ibadan 1979, P. 131 


\section{The Golden Age of Traditional Rulers}

The importance of the traditional rulers in the pre-colonial era was reflected in the various strong kingdoms that sprang up during this period.

The Republic of Benin incorporates an area where there had been many ancient kingdoms with powerful traditional rulers, prominent among which were the Kingdoms of Abomey, Porto-Novo and Nikki. Abomey was easily the most powerful of these Kingdoms. For our purpose, we shall examine the example of Abomey.

Traditional rulers in the ancient Kingdom of Abomey or "Danxome" occupied very important positions in all aspects of life. Politically, they directed all the affairs of the kingdom. But they were no despots as there were checks and balances instituted to moderate their activities. However, these checks and balances notwithstanding, all the political and administrative activities of the kingdom fell under their leadership. They issued orders and made laws which in principle had to be obeyed by all who resided in the kingdom.

Culturally, though Abomey Kings were not gods, they were sacred. They served also as intermediaries between the dead and the living. In addition, they were "worshipped" by their subjects, as they were considered the "Inspiration of life and the master of the Earth". ${ }^{2}$

The importance of the kings did not stop at the political and cultural levels. They also occupied an enviable position as the directors of the economic affairs of the kingdom. Theoretically and to some extent practically, these kings owned all lands and all that was found on the lands belonged to them. In short, they were the "masters of land" (Ainon); "the masters and possessors of all riches" (Doukounnon). As the holders of land in trust for the people the kings distributed parcels of land to the families for cultivation. It must be emphasized that customarily no farmer owned the parcel of land alloted to him as there was no alienation of land: he only had the fruits of his labour on the land. Each king did not only distribute lang but, through his minister of Agriculture, or "Tokpo", who was assisted by a corps of extensions workers, or "Houmekponto", he dictated the types of crops to be cultivated. In the nineteenth century emphasis was laid on the cultivation of palm products. It will be remembered that following the abolition of the slave trade at the end of the eighteenth century trade in oil palm became the principal source of revenue for all West African States situated along the Atlantic coast.

The king did not only encourage growth of this product among the peasant farmers, he too had plantations which were developed by the king's prisoners of war and by the peasant farmers, who spent sometime on the king's plantations. ${ }^{3}$ The kings also took taxes on the products of the peasants.

3 See Adassan, F. P., Vie rurale et phénomène migratoire dans le département du Zou. Thèse de Doctorat de Troisième Cycle, Toulouse 1975, pp. 7-9. 
For example, King Ghezo who reigned between 1818 and 1858 ordered that each peasant farmer made available one-eighth of all the revenues accruing to him from trade in palm oil. This tax, known as Kouzou, was collected on behalf of the King by the Tokpo minister of Agriculture. ${ }^{4}$

To further stabilize his financial position, King Ghezo controlled the activities of the foreign traders who transacted businesses within the Kingdom. He made sure that no foreign merchant traded directly with the native inhabitants of the Kingdom without formally obtaining approval from the King. To do this, he ordered all foreign traders to carry identity cards issued by the King. No one could establish himself in the Kingdom without the approval of the King.

Though we do not possess any statistical data on how much the King received from the taxes inposed on the population and how much he got from his personal plantations, it could still be said that he monopolized most, if not all, economic activities within the Kingdom. The king was aided to sustain his monopoly by his economic representatives and his secret agents located all over the kingdom. The secret agents were to see to it that no one undermined this monopoly, and any attempt to do so was reported to the King and the offender brought to book.

It is clear from the short analysis which we have just made that, during the pre-colonial days Dahomey Kings in the area of the present Benin Republic effectively controlled their subjects in all aspects of life. Their combined political, administrative cultural and economic powers was used by the kings to enrich themselves. The more reason why we consider this epoch as the 'Golden Age for the traditional rulers. The situation changed to the detriment of these rulers with the advent of colonization.

\section{Traditional Aristocracy under Colonial Rule}

The first consequence of colonization to any society is the loss of the sovereignty of such a society and consequently its demotion to the status of a dependent territory. ${ }^{5}$

As far as the traditional rulers were concerned, colonization resulted in the loss of the political and administrative leadership which these aristocrats had hitherto enjoyed among their people. In fact, these kings became mere official chiefs and instruments in the hands of the colonial administrators. They were used as necessary instruments for reaching the people and consequently for achieving the objectives of colonization with little or no cost at all to the imperial powers.

Stressing the imperative nature of the traditional rulers as tools for realising the goals of French colonization, a one-time Governor-General of the French West African State, Joost Van Vollenhoven, stated in 1917:

4 Ibid

5 See $N$ Talaja Nzongola: "Les chefs traditionnels dans l'administration coloniale au Dahomey et Sierra Leone" in Cahiers Zairois d'Etudes Politiques et Sociales. 1. April 1973. p. 95. 
Tout naturellement, le commandant de cercle recherche, pour assurer le succès de sa tâche, des intermediaires les plus qualifiés et du respect des populations. Ses recherches ne sont pas longues. Neuf fois sur dix cet intermediaire existe: c'est le chef traditionellement écouté et c'est ainsi que se pose le probleme des chefs non par déduction mais par simple bon sens et sous la pression de la nécessité ...6

In addition to turning the traditional chiefs into necessary instruments, the status of each chief or king was to be determined by the colonial administrators, notably the "Commandants de cercle". For example, in 1908, following the death of the King Toffa of the ancient kingdom of Porto-Novo, one of his sons who was to succeed him, was not allowed to do so in his capacity as king. Rather he was to be recognized as a senior chief (chef supérieur). ${ }^{7}$

Furthermore, chiefs were now appointed officially even when the existing ones had not died. This was to emphasize the absence of respect for African traditional systems of succession. An example of this disrespect for tradition was the appointment of a new King for Abomey after its conquest in 1894 by General Dodds. At a certain point "notables" were appointed into the royal palaces, with titles different from the traditional ones. ${ }^{8}$

Economically too, the traditional rulers lost the monopoly which they had hitherto enjoyed. The French colonialists made all efforts to seize all lands from them by promulgating the land act' of 1904. By this land act' it was expected that settlers, be they French or African, no longer had to apply to the indigenous kings and chiefs for the land they needed. ${ }^{9}$ This of course broke the economic backbone of the traditional rulers as their major source of revenue, land, was taken away from them. The above analysis, though short, shows clearly that during the colonial era, traditional rulers played the role which the colonial administrators wanted them to play.

In the local administrative machinery instituted by the French Colonial Master, at the outset of colonization, indigenous chiefs were appointed as official village headmen.

Those appointed as "canton" chiefs were chosen on the basis of their loyalty to the colonial administrators and not as a result of their ascriptive traditional positions.

The same goes for the village headmen. Where the colonial administrators "failed" to find "capable" indigenous "canton" chiefs, or village headmen, French administrators filled the existing vacancies.

Indigenous chiefs were appointed also as members of the Council of Notables. The Council whose president was the "Commandant de cercle" was charged with the respon-

6 Circular of 15th August 1917 quoted by J. J. Villandre in his thesis, titled, Les chefferies traditionnelles en Afrique Occidentale française, Thèse, Paris. 1950, p. 22.

7 See Adolphe Akindele and Cyrille Aguessy: Contribution à l'étude de l'histoire de l'ancien royaume de Porto-Novo Dakar, J.F.A.N. 1953. pp. 89-90.

8 See Rov Ronen, Dahomey Between Tradition and Modernity, Cornell University Press. Ithaca and London, 1975, pp. 43-45.

9 See Jean Suret-Canale, Afrique Noire Occidentale et Centrale, Tome 2, l'Ère Coloniale 1900-1945 Paris 1964, Editions Sociales, p. 97. 
sibility of advising the "Commandant de cercle" on matters relating to taxation and on how to ensure forced labour (travail forcé). ${ }^{10}$

When municipal administration similar to what obtained in the metropolis was introduced between 1919 and 1959, indigenous rulers participated in local administration, again, not as traditional rulers but as free citizens endowed with rights to be appointed or elected to offices as the case may be. ${ }^{11}$

To conclude this part of our discussion, it is pertinent to note that the attitude of the French colonialists was in reality similar to that of the British. The latter, too, despite their seemingly relaxed approach compared with the vigorous approach taken by the French, subordinated the traditional authorities to colonial administration. The British adapted the traditional institution to suit their purpose and they removed any traditional authorities who became recalcitrant or in any way constituted an obstacle to the realisation of British colonial objectives. ${ }^{12}$

The rude shock experienced by the traditional rulers was to continue, and was even intensified after independence. In fact, in some cases, there were outright legal abolitions of traditional rulers, such as in Guinea in 1957 and in Burundi in 1960. Other countries which legally abolished the chieftaincy institution include Rwanda in 1962 and Zaire in 1973. There was a de facto abolition of the institution in Mali just before independence in $1960 .{ }^{13}$ It should be mentioned that some other countries thought of reorganizing the chieftaincy institution. Thus Senegal in 1960, Upper Volta in 1964 and Central Africa in 1959 took steps to reorganize the institution. Some thought of integrating the institution into the administrative network at the level of Communes as, for example, Cameroon in 1959 and in 1966. Finally, Congo Brazzaville attempted to transform the institution in 1967 and adapt it to the contemporary political and administrative framework. ${ }^{14}$ The question now is: What happened to this traditional institution in the Republic of Benin at the time of independence and what is the attitude to it of the current leaders. More importantly, what has been their (the traditional rulers') position in local administration?

10 See Virginia, T. "Dahomey" in Five African States edited by Carter, G. M. New York 1963. pp. 161-167.

11 For details on the communal administration see "Evolution politique de l'Afrique Noire. Association française de science Politique", Table Ronde March 1959, p. 56 and subsequent pages.

12 For some interesting comparative studies on the attitude of the French and the British towards African traditional aristocracy;

(i) Asiwaju, A. I. "The Alaketu of Ketu and the Onimeko of Meko: The changing status of two yoruba rulers under French and British rule" in Crowder, $M$. and Ikime, $O$. (eds.) West African chief s: Their Changing status under Colonial rule and independence, University of Ife Press 1970, pp. 134-162. The whole book adopts a comparative approach towards analysing the experience of African traditional rulers under the two major colonial powers (The French and the British).

(ii) Lombard, J., Autorités Traditionelles et Pouvoirs Européens en Afrique Noire. Librairie Armand Colin 1967.

13 See E. Le Roy, "Les chefferies traditionnelles et le problème de leur integration" in G. Conac (Sous la direction de) Les Institutions administratives des Etats Francophones d'Afrique Noire. (Economica 1979, p. 114).

14 Ibid. 


\section{Traditional Rulers, New Political Leaders and the Operation of Local Administration after Independence}

At independence, the new political leaders deposed the traditional rulers constitutionally. This was a consequence of the colonial legacy. It will be remembered that the constitution adopted in Benin, just as in other French West African States with the exception of Guinea, reflected the republican constitution of the former colonial master, which advocates equality of man, the liberty of all and the abolition of monarchy. ${ }^{15}$ In the light of this, there was no specific role assigned to traditional rulers in the management of the local administrative machinery.

The machinery which on the whole was a reproduction of the apparatus set up by the French colonial master, though the former six regions became Departments, was administered by officials oppointed and/or elected. For example Prefects were appointed to the six existing Departments. Sub-Prefects were also appointed to the sub-Prefectures. ${ }^{16}$ When the Communal system was re-introduced in $1964^{17}$ after its disappearance on 26th February $1962,{ }^{18}$ the mayors who administered the communes were chosen by election based on universal adult suffrage. The same goes for the various administrative organs of the Village - the lowest level of the local administrative set up. ${ }^{19}$

The struggle against monarchy did not point towards nor lead to the disappearance of the traditional rulers in Benin Republic. A more realistic appreciation of what actually obtains would be to see this traditional institution as co-existing and interacting with the modern political and administrative system. It should be remembered that the majority of the people in Benin are illiterates by European standards, and these people are closely attached to their customs and traditions which encourage maximum respect for the traditional rulers despite the confusion created in the relationship between these people and their native rulers by the colonial masters. ${ }^{20}$

It is important to note that Benin and its social organization do not constitute a tabula rasa on which a new system could easily be planted. However, we still maintain that, despite this interaction, the traditional rulers do not occupy any official position in the operation of local administration because of their traditional positions. Those who participate in the running of the affairs of the local administrative set-up do so as ordinary citizens without any recognition for their traditional position. Anthony Asiwa$j u$ gave us the example of an Alaketu who was elected to the post of the Village headman

15 See Glele, M. A., "Le modèle Constitutionnel Français et son influence sur les Etats Africains liés à la France“ in La Politique Africaine du General de Gaulle 1958-1969. Colloque de Bordeaux 19-20 October 1979.

16 See Journal Officiel de la République du Dahomey J.O.R.D. (Official Gazette) 1st November 1960; p. 673.

17 See Article 20 of the Law No. 64 - 15 of 11 th August 1964 in Journal Official de la République de Dahomey J.O.R.D. (Officiel Gazette) 17th August 1964; p. 534.

18 See J.O.R.D. 1st March 1962, p. 289.

19 See "Loi Organique, No. 59-36" of 31st December 1959 in J.O.R.D., 31 st December 1959, p. 902.

20 See Gonidec, P. F., L'Etat Africain L.G.D.J. Paris, 1970 pp. 238-239. 
on 13th January $1964 .{ }^{21} \mathrm{He}$ went further to clarify the distinction between the choice of the Alaketu as the village headman according to the constitutional provisions and the coronation of the same man as the Alaketu by custom in November 1965.22

From the analysis of Asiwaju one could see that there is a difference between the perception of the people of Ketu of the position of the Alaketu as their leader and the method of his choice, and that officially recognized by the new political leaders of the post-colonial state. Whereas the ruling political elites were satisfied in merely appointing the Alaketu officially, to legitimize his authority over the people of Ketu, these people, insisted on formalizing the authority of the Alaketu through traditional rites. The attitude of the political elites was a demonstration of the non-recognition of the traditional position of the traditional aristocracy. But the attitude of the people of Ketu shows the survival of customs and traditions in Ketu and the commitment of the natives to these traditions.

However, in spite of this non-recognition of the traditional position of the native chiefs and kings, the new political leaders, just as the colonial masters, need and make use of these chiefs to reach the local populace. But the purpose of the post-colonial political elites was different from that of the French colonial authorities. The political leaders exploit the influence of the traditional rulers to secure legitimacy for leadership from the masses and to secure their votes at elections.

They also benefit from the influence of these traditional authorities on their people to maintain law and order in rural areas. Briefly they (traditional rulers) are de facto law enforcement agents. The political leaders utilise these traditional ruling elites to mobilize the citizens for tax collection. All we are saying is that, although the political structures do not have any official roles for the traditional rulers, they cannot be ignored socially. In February 1974, a reform was carried out on the local administrative machinery by the current regime of Brigadier (then Colonel) Mathieu Kerekou. The existing administrative machinery was considered as anachronistic. This was implied in the statement of Brigadier Kerekou who said:

... Sur le plan organisationnel, le système reste de type napoléonéen, vestige de la période coloniale. La centralisation des structures étouffe les initiatives et l'ésprit de responsabilité. Elle eloigne le pouvoir des citoyens. ${ }^{23}$

In essence, Kerekou accused the former regimes of centralization and for not allowing initiatives to be taken by the people. These regimes were also accused of not drawing administration nearer to the people. This ist not the place to argue whether Kerekou's

21 See Asiwaju, A. I. "The Alaketu of Ketu and the Onimeko of Meko . . op ... cit.

22 Ibid.

23 See "Gouvernement militaire Révolutionnaire, Discours Programmes du Colonel Mathieu Kèrèkou, le 30 Novembre 1972“ Editions, Office Nationale d'Edition Presse et Imprimerie. O.N.E.P.I. Cotonou, December 1972 
accusation is justified or not. ${ }^{24}$ Our main concern is to identify the position of traditional authorities in the newly instituted administrative apparatus.

Following the reform of 1974 , six provinces replaced the former Departments. The provinces were divided into urban and rural Districts. Furthermore, the Districts were subdivided into urban and rural communes, and finally, the village administration at the lowest level of the administrative structure was maintained, though with little modification in its structure.

At the different levels, the recruitment of officials to administer these structures is again by appointment in the case of the prefects and the District heads (as at 1974), and by election of mayors and village heads.

Another reform was carried out on the local administration in 1982. This reform centred mainly on a complete politicization of the different administrative institutions at the local level. The reform also claims to have generalized the method of election in choosing all categories of local administrative officials. ${ }^{25}$

The socialist ideology "adapted" to Benin's social realities which led to the formulation and adoption of a new constitution in 1977 (La Loi Fondamentale) renders the traditional institutions the more irrelevant to the current structures of authority. Under the new dispensation, no role is assigned, just as in the past, to the traditional chief $s$ in their capacity as ascriptive leaders. But it must be noted that representatives of the government have met with stiff resistance from the traditional rulers in the implementation of the reforms which began since 1974. For example in Nikki, in the North, it was reported that the traditional ruler there refused to allow his people to elect a new mayor, as he presented himself as the natural mayor of the people. In this regard, the traditional ruler insisted on forcing his authority on his people. He also tried to make the political representatives of the government and eventually the authorities in Cotonou realise that any attempts by the latter to appoint another ruler for the people of Nikki was a violation of the traditional methods of choosing the rulers of Nikki.

Still on Nikki, it was reported that as a result of the uncooperative attitude of the traditional ruler with the representatives of the government in implementing the new local administrative reforms the then minister for Interior and Security the late Captain Aikpe, visited Nikki. In an attempt to enforce the new order of the government on the reforms, he slapped the traditional ruler because the latter remained adamant.

As a result of this, the minister was cursed by the traditional ruler. This minister met his death three days after leaving Nikki. The public did not believe the official version of the cause of the death of Captain Aikpe. Rather, they were prepared to believe that his death was a consequence of the curse by the traditional ruler in Nikki. This is to say that, the people in Benin still hold to the belief that their traditional rulers are endowed with

24 See S. Bamidele Ayo; "L' Administration Locale et le Développement Rural en Republique du Benin de 1960 à 1981" Thèse de Doctorat, Bordeaux, October 1982, pp. 188-200.

25 See, "Loi Organique No. 81009 " of 10th October 1981, on the creation, organization and functions of the various local organs of State power. 
divine powers. The traditional ruler concerned and the people of Nikki might have been tempted to believe in the supremacy of the traditional system of administration over the modern system. The traditional ruler evidently believed that he could assert his traditional rights against the modern political elites. In our view, the incident in Nikki shows that the powers of traditional rulers are informal, but these powers are real. Judging also from our discussion with many of the provincial Prefects and District heads (Chefs de District) and even the mayors of many of the Communes, there is an inherent respect, if not fear, of the traditional institution and the traditional ruling elites by the modern political leaders.

It is also interesting to note that recently an administrative council was set up for the members of the Abomey royal family. Although the government claims that by setting up the Council, the traditions of Abomey would be protected; in addition the council would ensure the protection of the interests of the members of the royal family; the Council would also serve as a forum for disseminating knowledge on the customs of the various Abomey dynasties. ${ }^{26}$ But in reality, the Council was set up to facilitate the monitoring of the activities of the members of the royal family by the government. The need to monitor the activities of the members of the royal family arose when it was rumoured that these members were making attempts to thwart the efforts of the government at implementing the new local administrative reforms. In addition, the government feared that these members of the royal family might paralyse the revolutionary activities which it had embarked upon since October 1972. This is why the Minister of Interior and Security plays an important role in the Administrative Council for the royal family.

Membership of the Council is subject to the approval of the Minister of Interior and Security, as article 4 of the law creating the council clearly indicates. ${ }^{27}$

\section{Conclusion}

In the Republic, of Benin traditional institutions have no constitutional role, but in social reality, their influence on their people waxes stronger, especially in the rural areas where the majority of the population resides. As mentioned at the opening of this essay, the situation in Benin is not unique to that country. It is the prevailing situation in very many African states. In all these states, though efforts are intensified to reduce to its possible minimum the powers of the traditional rulers, and to deny them participation in the day to day running of administrations or governments, this institution has weathered all storms which attempted its removal. Regimes, be they military or civilian, have been forced to reckon with the traditional institution.

26 See Journal Officiel de la République du Dahomey J.O.R.D. (Officiel Gazette) 1st February 1975.

27 Ibidem. 


\title{
ABSTRACTS
}

\section{Participative Law-Making: A New Approach to Drafting Cooperative Law in Developing Countries}

\author{
By Hans-H. Münkner
}

\begin{abstract}
After a short introduction to the problems of law and development in countries having parallel (autochthonous and imported) legal systems and the identification of cooperative law as a special field of legislation, where the requirements of the target populations both in the informal and in the "modern" sector of the economy have to be met, different forms of law-making in developing countries are reviewed: the conventional process of law-making, administrative short-cuts to new legislation and a proposed new form of participative law-making.

The shortcomings of current cooperative legislation are discussed against the background of general problems of law-making in developing countries.

The proposed participative approach to making new laws by taking the law-making process to the target population may help to solve the problem of ineffectiveness of "modern" laws in developing countries. In the main part of the paper the concept of participative law-making and a seven-step process of implementation are described and suggestions are made how this new approach to law-making in a field of law affecting the socio-economic conditions of the masses of the population can be carried out with the help of foreign aid organizations.
\end{abstract}

\section{Traditional Rulers and the Operation of Local Administration in the Republic of Benin}

\section{By S. Bamidele Ayo}

The role of Traditional Rulers in government at the local level has recently generated much academic debate. There are advocates of formal politico-administrative roles for Traditional Rulers in the management of local affairs; on the other hand there are those who believe that Traditional Rulers have outlived their usefulness and as such have nothing to contribute to the business of local government. This latter group has even advocated the abrogation of the institution of Traditional Rulership in Africa.

This paper examines the attitudes of successive governments in the Republic of Benin to the institution of Traditional Rulership, particularly their role in the operation of grassroot administrative machineries. According to the analysis in the paper, formal participation of Traditional Rulers in local Administration in the Republic of Benin ended with 
the colonial administration. Since independence, African leaders who took over the affairs of the country have made strenuous efforts to formally exclude the Traditional Rulers from the management of local administration. Brigadier Mathieu Kerekou's socialist regime has been the most committed to the insulation of Traditional Rulers from participating in the running of local administration in the Republic of Benin. However, one thing is common to all post-independence regimes in Benin: no government has succeeded in practically abrogating the institution of Traditional Rulership. On the contrary these regimes have been obliged to reckon with the Traditional Rulers socially and for the achievement of their political ambitions.

\section{Paraguay's Muncicipalities: An Analysis of their Financial and Personnel Capacity}

\section{By Jürgen Wolff}

The article is devoted to an analysis of the effectiveness and the efficiency of Paraguay's municipalities in view of the many development tasks conferred upon them by law. It concentrates on financial and manpower (public service) matters.

Concerning the first point, the assessment is markedly negative: despite a marked deconcentration of public affairs, only $4 \%$ of public expenditures are controlled by the municipalities - and two third of these by the capital, Asunción. The municipalities of the interior simply lack the necessary funds to perform their duties in a satisfactory manner. Hence, state corporations come into play and invade "municipal" matters.

Secondly, concerning public officials, the picture is not much better: training is inadequate, especially concerning correspondence between training and job requirements; turnover is high, and institutions of follow-up training insufficient. In addition, there is, until now, no career public service at the municipal level.

On the whole, the centralist tradition of public administration has much weakened the Paraguayan municipalities. They simply are not in a position to assume their tasks as they are expected to according to law and constitution. This could only be changed by far-reaching financial and public service reforms.

\section{The IMF Policy of Stabilization}

\section{By Joachim Betz}

The importance of the International Monetary Fund (IMF) for the financing of balance of payments deficits of developing countries has grown significantly during the recent debt crisis and has also given rise to a renewed discussion of the Fund's credit conditionality. 